\title{
Syringocystadenoma Papilliferum of The External Auditory Canal: Case Report and Literature Review. SCAP of the EAC - Case Reports
}

\author{
Juliana Cristina Mesti, Inaê Mattoso Compagnoni, Trissia Maria Farah Vassoler, Gilberto da Fontoura Rey Bergonse, \\ Mariana Nagata Cavalheiro, Bruno Amaral Hay, Rafaela Mabile Ferreira dos Santos Sobreiro*, Rodrigo Marques \\ Borburema and Rodrigo Alvarez Cardoso
}

Hospital Cruz Vermelha, Paraná, Brasil

Submission: July 02, 2018; Published: July 13, 2018

*Corresponding author: Rafaela Mabile Ferreira dos Santos Sobreiro,Rua Visconde do Rio Branco, 1102,MercêsCuritiba, Paraná, Brasil, Tel: 5541999572835; Email: rodrigo.borborema@yahoo.com.

Abstract

CAAconsulted with a hypoacusis tinnitus and atrial fullness on the left ear.CT of the ears and histopathological whose diagnosis was SCAP. SCAP is a benign neoplasm rare in EAC, but because it is a benign tumor with potential for malignancy,suspicion of diagnosis is important.

Keywords: SyringocystadenomaPapilliferum; Tumors Epidermal Appendages; SCAP

Abbreviations: CT: Computed Tomography; EAC: External Auditory Canal; HPV: Human papiloma virus; SCAP: Syringocystadenoma Papilliferum; WHO: World Health Organization

\section{Introduction}

Syringocystadenomapapilliferum (SCAP) is an uncommon benign adnexal neoplasm $[1,2]$, which is frequently located on the scalp, with extremely rare appearance in the external auditory canal (CAE) [3,4].Its origin is still uncertain, but it is believed to be apocrine [4], Syringocystadenomapapilliferum is mostly associated with other benign neoplasms, where sebaceous nevus is involved in $40 \%$ of the cases [3,5].The clinical signs vary from asymptomatic patients to hearing loss and the diagnosis is based on histopathological evaluation [6].

\section{Case report}

A 49-year-old female patient was seen in the otorhinolaryngology department due to hearing loss, tinnitus and left atrial fullness which have begun 6 months ago. She reported improvement in symptoms as she pressed the lobe from the left ear downwards. She had no previous history of otitis, or otological traumas. Physical examination revealed a bulging of the upper region of the left external auditory canal causing its total obstruction, and it was not possible to visualize the tympanic membrane and without local cutaneous alterations. Audiometry showed moderate to severe conductive hearing loss on the left and audiometry with left b-curve. A computed tomography scan of the ears was performed showing well-developed mastoid, with no soft tissue material, with left ear canal stenosis.The patient was submitted to a surgery in order to excise the lesion and the material was sent for anatomopathological study, which resulted in syringocystadenomapapilliferum of the external auditory canal and absence of malignancy. Patient remains on outpatient follow-up.

\section{Discussion}

Syringocystadenomapapilliferum EAC was first described in 1971 by John Stokes [7]and it is an uncommon benign neoplasm whose origin is still uncertain.In about $50 \%$ of cases, SCAP is present at birth and in 15\% it appears until infancy [6].Therefore, it appears to be a tumor originated from undifferentiated cells with differentiation potential for eccrine cells or, more commonly, apocrine cells $[4,5,8]$.0ther studies also point to the possibility of involvement of human papillomavirus (HPV) in the genesis of this tumor [6].In 2004, Thompson et al updated the WHO (1991) and Wetli (1972) classifications and divided the lesions into: benign, which includes cerumen, pleomorphic and papillary adenomas and malignant adenomas (adenocarcinomas). Until 2016, there are only 150 reports in the literature of tumors of ceruminous glands, which only 11 are papillary seringocystadenoma[6].

When present in the EAC, the clinical manifestations of the tumor vary and depend mainly on its development, once they may show as masses or ulcers. Initially, it is an asymptomatic disease, however, due to its growth, it can evolve to a sense of atrial fullness, cerumen impaction, external otitis and conductive hearing loss[6]. Although there is rarely malignant 
transformation, there are already cases described in the literature of papillary syringocystadenocarcinoma[9].The diagnosis is given by the histopathological evaluation of the tumor, observing «cup» epithelial lesions frequently cavitated and covered by a layer of hyperkeratosis and acanthosis that invaginate and form the papillae. Imaging examinations, such as computed tomography and magnetic resonance imaging, may be useful to assess the extension, aiding in preoperative evaluation [9].There is no recommended treatment yet, however, it is suggested that the excision of the lesion be performed with or without graft and follow-up indefinitely.

\section{Conclusion}

SCAP is a rare benign tumor of uncertain origin with better therapeutic care and follow-up yet to be defined. Because there is a potential for malignancy, it is of the utmost importance that studies be performed to establish the conducts to be taken in case of this tumor.

\section{References}

1. Böni R, Xin H, Hohl D, Panizzon R, Burg G (2001) Syringocystadenoma papilliferum: A study of potencial tumor supressor genes. Am J Dermatopathol 23(2): 87-89.
2. Karg E, Korom I, Varga E, Ban G, Turi S (2008) Congenital Syringocystadenoma papilliferum. Pediatr Dermatol 25(2): 132-133.

3. Philipone E, Chen S (2009) Unique case: Syringocystadenoma papilliferum Associated with an eccrine nevus. Am J Dermopathol 30(8): 806-807.

4. Townsend C, Bowen R, Nobuhara k (2004) Syringocystadenoma papilliferum: An unusual cutaneous lesion in a pediatric patient. J Pedia tr 145(1): 131-133.

5. Barbarino S, McCormick A, Lauer SA, Milman T (2009) Syrincocystadenoma Papilliferum of the Eyelid. Ophtal Plast Reconstru Surg 25(3): 185-188.

6. Arechvo A, Balseris S, Neverauskiene L, Arechvo I (2013) Syringocystadenoma papilliferum of the bony external auditory canal: a rare tumor in a rare location. Case Rep Otolaryngol 2013: 541-679.

7. Jordan A, Brown E, Biavat MJ, Manning C (1996) Congenital syringocystoadenoma papilliferum of the ear and neck treated with the $\mathrm{CO}_{2}$ laser. Int $\mathrm{f}$ Pediatric Otorhinol 38(1): 81-87.

8. Lever F, Ahmed S (2009) Tumors of the epidermal appendages Lever's Histopathology of the Skin. 10: 879-880.

9. Liu SC, Kang BH, Nieh S, Chang JL, Wang CH (2012) Adenoid cystic carcinoma of the external auditory canal. J Chin Med Assoc 75(6): 296300 .

\section{Your next submission with Juniper Publishers will reach you the below assets}

- Quality Editorial service

- Swift Peer Review

- Reprints availability

- E-prints Service

- Manuscript Podcast for convenient understanding

- Global attainment for your research

- Manuscript accessibility in different formats

( Pdf, E-pub, Full Text, Audio)

- Unceasing customer service

Track the below URL for one-step submission https://juniperpublishers.com/online-submission.php 